\title{
A story of urban farming and the cultivation of community and the human spirit
}

\author{
Matthew M. Mars* \\ The University of Arizona
}

Review of Street Farm: Growing Food, Jobs, and Hope on the Urban Frontier, by Michael Ableman. (2016). Published by Chelsea Green Publishing. 256 pages; available as paperback and ebook.


Publisher's website: http://www.chelseagreen.com/farm-garden/street-farm

Submitted September 2, 2016 / Published online November 14, 2016

Citation: Mars, M. M. (2016). A story of urban farming and the cultivation of community and the human spirit [Book review]. Journal of Agriculture, Food Systems, and Community Development, 7(1), 135-136. http://dx.doi.org/10.5304/jafscd.2016.071.004

Copyright (C) 2016 by New Leaf Associates, Inc.

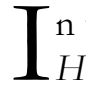
$\mathrm{n}$ the book Street Farm: Growing Food, Jobs, and Hope on the Urban Frontier, Michael Ableman tells the story of how an urban farm has transformed vacant lots in the Low Tracks neighborhood of Vancouver, British Columbia, into sites where food is produced, community is in part restored, and the human spirit is nurtured. Ableman's storytelling is raw and transparent. Through this transparency, he reveals a tenuous balance between the promises of urban farming and the harsh realities of the

* Dr. Matthew M. Mars is an assistant professor of agricultural leadership and innovation in the Department of Agricultural Education at The University of Arizona. Dr. Mars teaches and studies entrepreneurial strategy in the context of agricultural innovation, community leadership, and social change. His current work largely centers on the diffusion of innovations across local and regional food systems and how such diffusion may or may not occur through the implementation of entrepreneurial leadership strategies. He can be reached at mmars@email.arizona.edu addiction, hunger, homelessness, and violence that often characterize inner-city conditions. This balance illustrates how urban agriculture can help produce the food a city needs in a sustainable way and, perhaps more importantly, feed the souls of disenfranchised individuals and communities.

The book is not developed around the technological aspects, economic opportunities, or socio-political underpinnings of urban farming or its promise to be an alternative to industrial agriculture, as one might expect. Instead, Ableman features urban farming first and foremost as an innovative approach to the nurturing of human dignity, hope, and talent within disenfranchised communities that are too often ignored and left in decay. Sole Food Street Farms, a network of four urban farms located throughout the impoverished fringe of the otherwise affluent Vancouver downtown district, is both the setting of the story and the vehicle for its plot. The farms introduce a cast 
of real-life characters who are attempting to overcome the ill effects of poverty and diseases such as drug and alcohol addiction, diabetes, and schizophrenia. As such, readers come to know these individuals not only through their real and constant pains and struggles, but also through the emotional and physical healing they achieve by working on the farms. The compelling examples of the farms and the pride that the farmers develop in their work converge to tell a story of the potential power of agriculture as a development tool in even the most unlikely of places. Community development practitioners and scholars alike will gain inspiration and new ideas for their own work through this compelling narrative.

The approach Ableman takes in structuring the book is both pragmatic and strategic. Pragmatically, each chapter builds upon the next in a way that clearly presents the evolution of Sole Foods Street Farms from an early-stage idea to a well established community asset. Along the way, challengesranging from shortages in funding and uncertain lease agreements to vandalism and to the unpredictability of the street farmers themselves-are described with rawness and honesty. In doing so, Ableman provides readers with a holistic understanding of both the rewards and hardships that come with starting and operating an urban farm that is not only in the business of producing food, but also in nurturing people and developing communities.

More strategically, each chapter reveals a new layer of the human complexities associated with urban farming in marginalized communities. Readers are continually exposed to the economic, political, and technological realities that confront a group of social entrepreneurs who are working to transform a community through the farming of some of the most unlikely urban spaces (e.g., vacant lots plagued by contaminated soils). Yet the focus rightfully remains mostly on (or reliably returns to) the individual farmers who find meaning and refuge on the farms. This spotlight on the human element of farming and the renewal it stands to bring to both individuals and communities is what makes Ableman's book a provocative and deeply engaging read.

Ableman also provides scientific and technological guidance throughout the book in a clever and effective way. Each chapter includes a sidebar featuring brief insights and practical tips on the craft of urban farming. Examples of these inserts include the estimated production capacity of a parking-space-sized plot, pest and plant disease management, and proper posture when cultivating and harvesting urban crops. This approach allows Ableman to avoid the tendency of many alternative agriculture texts to become overly complicated scientific and technological treatises rather than engaging, informative narratives. Street Farm is far from a "how to" manual for urban farming, but the inserts give those with urban farming aspirations a realistic idea of the many facets of the work they will need to consider should they act on their interests.

Ironically, Ableman never directly connects urban farming with the conditions of hunger and malnutrition, which readers are likely to expect given the mission and location of Sole Foods Street Farms. Instead, Ableman makes the odd choice to frame food security in the context of environmental and economic sustainability. This subnarrative is developed with a relatively reflective and objective tone that is likely to appeal to a broad audience of individuals with a range of economic, political, and socio-cultural views. Yet this reviewer was often left wondering how, if at all, the farms help feed the "street farmers" who are highly vulnerable to hunger and its many physiological and psychological effects. The discussion of the challenges and opportunities of selling urban-grown produce to high-end restaurants is somewhat off-putting given the book's lack of attention to feeding those suffering from hunger on the streets surrounding the farm, which are home to the farmers themselves.

Beyond the one preceding criticism, Street Farm: Growing Food, Jobs, and Hope on the Urban Frontier is an extremely well written account of the human and community dynamics of urban farming. The experiences and perspectives shared by Ableman are likely to catalyze new ideas and strategies for expanding urban farming in productive and fruitful ways. Most importantly, this piece will help remind practitioners and scholars of the importance of individual and community wellness to the urban farming movement. 